\title{
Clinico Therapeutic Studies on Ascites in Canines
}

\author{
Sachin Kumar Singh ${ }^{1}$, S. K. Shukla ${ }^{2}$, Prakash Bhatt ${ }^{2}$ and A. K. Singh ${ }^{3^{*}}$ \\ ${ }^{1}$ Udham Singh Nagar Dairy Cooperative Limited, Pithoragarh, Uttarakhand, India \\ ${ }^{2}$ Department of Veterinary Clinics, Veterinary Clinics, College of Veterinary and Animal \\ Sciences, Govind Ballabh Pant University of Agriculture and Technology, Pantnagar, India \\ ${ }^{3}$ Department of veterinary medicine, Pantnagar, India \\ *Corresponding author
}

\section{Keywords \\ Ascites, haemato- biochemical, hypoproteinemia, hypoalbuminea and hypoglobulinemia, therapeutic, cannines}

\section{Article Info}

Accepted:

14 August 2019 Available Online: 10 September 2019

\section{A B S T R A C T}

A total 18 dogs maintained at different places were screened and included in the study. All the dogs were put through preliminary screening for the presence of ascites and were subjected to thorough clinical examination including detailed physical and clinical investigation with special reference to haemato-biochemical estimation, ultrasonography and radiography. The dogs found positive were subjected to therapeutic study and were further divided into three groups, namely G II, G IIIand G IVcomprising of 6 animals in each group irrespective of their sex, breed and age. Another group i.e., GI comprising of 6 apparently healthy dogs served as negative control during the study period. The dogs in group $\mathrm{G}_{1}$ were treated with Silymarin$7 \mathrm{mg} / \mathrm{ml}$ orally, $\mathrm{G}_{2}$ group of dogs were treated with syrup containing Tricholine Citrate, Vitamin $\mathrm{B}_{12}$, Inositol, Methyl donors, Selenium, Vitamin $\mathrm{E}$ and Biotin in a base enriched with liver extracts whereas dogs in group $\mathrm{G}_{3}$ were treated with Alfalfa, Avena Sativa, Ashwagandha, Acid Phosphoricum, China, Hydrastis Canadensis, Five Phos, total medication $6.35 \%$, in syrup base. The drugs were given @ 2 tsf of syrup for 45 days. In addition to the specific drugs, common ancillary and supportive treatment was also given. On hematological analysis, there was significant decrease in haemoglobin, PCV, lymphocyte and TEC values in ascitic dogs. No significant change was found in eosinophil and basophil count. Hypoproteinemia, hypoalbuminea and hypoglobulinemia with increased ALT, AST, ALP, GGT, TLC, BUN and creatinine levels were main serum biochemical changes recorded in ascitic dogs. Clinical signs and vital parameters were noticed to have improved after treatment in all the three groups but better improvement was noticed in group $G_{1}$ which was treated with silymarin. 


\section{Introduction}

Ascites refers to the over accumulation of transudate within the peritoneal cavity (Saravanan, 2013). It is one of the most commonly found abdominal abnormalities of dogs (Hunt, 2002). This condition may occur in portal hypertension, hypoalbuminemia and renal retention of sodium and water.

Ascites has also been attributed to conditions like chronic hepatic failure, congestive heart failure, malnutrition and ancylostomiasis (Randhawa et al.,1988).

The development of ascites occurs while there is an alteration in starling's forces, including accelerated venous or lymphatic hydrostatic strain, vascular permeability, extended intraperitoneal oncotic stress and decreased capillary oncotic pressure.

In dogs with chronic liver disease causing an intrahepatic portal hypertension, the ascitic fluid is clear and colourless pure transudate containing very few nucleated cells, less protein concentration and specific gravity (1.016).

Due to right sided heart failure in case post sinusoidal hypertension, the fluid is slightly cloudy modified transudate which contains protein concentration of $2.5-5.0 \mathrm{~g} / \mathrm{dl}$ with nucleated cells less than $7000 \mathrm{per} \mathrm{ml}$ and specific gravity of 1.017- 1.025, exudates contain protein concentration more than 2.5 $\mathrm{gm} / \mathrm{dl}$, More than 7000 nucleated cells per $\mathrm{ml}$ and specific gravity of more than 1.025 in abdominal tumour or peritonitis (Steiner, 2008).

Liver damage can be diagnosed and monitored using biochemical tests of liver markers such as assessment of hepatic blood flow, prothrombin time or serum markers such as serum bilirubin, serum transaminases (Kamble et al., 2009), serum alkaline phosphatase, gamma-glutamyl transferase (Ola-EL-Segay et al., 2007), glucose (Banerjee,2003) and total protein and albumin levels (Tiwari et al., 2001). Complete blood count, serum biochemical profile, urine analysis, faecal analysis, survey of abdominal radiography (Varshneyand Hoque, 2002) and ultrasonography (Vijayakumar et al., 2011) are considered for screening purpose interestingly, some liver diseases are characterized by subtle changes in liver enzyme activity with normal functional indices, thus complicating the diagnosis.

\section{Materials and Methods}

Total 18 animals maintained at different places were screened and included in the prevalence study. All the dogs were put through preliminary screening for the presence of ascites.

It consisted of history taking, recording of temperature, pulse, respiratory rate, heart rate and level of dehydration. Dogs showing clinical signs of distended abdomen, decreased appetite, lethargy, vomiting, diarrhoea, melena, weight loss and mild jaundice, were subjected to thorough clinical examination including detailed physical and clinical investigation with special reference to haemato-biochemical estimation, ultrasonography and radiography. The dogs found positive were subjected to therapeutic study.

\section{Grouping of animals}

On the basis of preliminary screening, 18 screened dogs affected with ascites were divided into three major categories i.e. Group II Group III, Group IV, comprising of 6 animals in each group irrespective of their sex, breed and age. Another group of 6 healthy dogs, who so ever were subjected for health 
screening were taken as healthy group and were designated as group I.

\section{Biological samples collection}

\section{Blood collection and storage}

To study haemato-biochemical alteration in ailing as well as healthy dogs, blood samples were collected from all the dogs of various groups before and after treatment.

About $5.0 \mathrm{ml}$ of venous blood sample was collected by dry disposable syringe through saphenous or cephalic vein from each dog, Immediately after collection about $2.0 \mathrm{ml}$ blood was transferred to EDTA (@ $1.5 \mathrm{mg} / \mathrm{ml}$ ) vials for complete blood count (CBC) that was carried out within four hours of collection.

Left over, $3.0 \mathrm{ml}$ of blood was transferred in to a clean and dry test tube without any anticoagulant and was allowed to clot in slanting position for about one hour and then separated serum was collected gently after centrifugation for 5 minutes at 3,000 rpm.

The supernatant serum was collected carefully in a dry eppendrof tube with the help of micropipette and finally the well labelled sera samples were preserved at $-20^{\circ} \mathrm{C}$ in a deep freeze for further biochemical and serological estimation.

The blood samples were collected before and subsequent days after treatment from all the animals of various groups.

\section{Clinico-pathological studies}

Overt clinical signs and pathological observations were recorded from all the dogs, which were taken for this study, irrespective of their breed, age and sex suffering from ascites just before and after treatment i.e. on day- $0,15,30$ and 45 .

\section{Haematological profile studies}

The blood samples were analyzed instantly after collection for following parameters, using standard laboratory procedures described by Jain (1986).

\section{Haemoglobin(Hb)}

Haemoglobin concentration was estimated using Sahli'sHaemoglobinometer by acid haematin method as described byOser (1976) and results were expressed in $\mathrm{g} / \mathrm{dl}$ of blood.

\section{Total erythrocytes count (TEC)}

The total erythrocyte count was done as per method described by Jain (1986) using Hayem's fluid and results were expressed in million per microliter $\left(\times 10^{6} / \mu 1\right)$.

\section{Packed cell volume (PCV)}

Packed cell volume was estimated by microhaematocrit method, explained by Schalm et $a l$. , (1986) and the values were expressed in percentage $(\%)$.

\section{Total leukocytes count (TLC)}

TLC was estimated with the help of haemocytometer(Jain, 1986) using Thomas diluting fluid and results were expressed in thousands per microliter $\left(\times 10^{3} / \mu 1\right)$.

\section{Differential leukocytes count (DLC)}

Thin blood smear was made over a clean grease free glass slide using a drop of blood.

The smear was air-dried and stained with Leishman's stain.

The different leukocytes were counted by battlefield method and values were expressed in percentage using blood cell counter. 


\section{Total platelets count (PLT)}

The total platelet count was done by using Rees Ecker diluting fluid with improved Neubauer's counting chamber according to Rees and Ecker method described by Seiverd (1983). The number of cells counted was multiplied by 2000 to give number of platelets (x $10^{5} / \mu 1$ of blood).

\section{Biochemical estimation}

\section{Blood urea nitrogen (BUN)}

The BUN was computed through multiplying the value of blood ureaby 0.46 (Fingerhunt et al., 1966) using a reagent kit from Erba diagnostics and the results were expressed in $\mathrm{mg} / \mathrm{dl}$. Serum creatinine. Estimation of serum creatinine was done by the method of Bonses and Taussky (1945), using a reagent Kit obtained from Erba diagnostics and the results were expressed in milligram per decilitre (mg/dl).

\section{Total serum proteins}

Estimation of total protein was done by modified Biuret method described by Varley et al., (1980), using the Erba diagnostics kit and the results were expressed in gram per decilitre $(\mathrm{g} / \mathrm{dl})$. Albumin by Dumas method (Varley et al., 1980).

\section{Globulin}

To calculate serum globulin the total serum albumin value was subtracted from the value of total serum protein and results were expressed in $\mathrm{g} / \mathrm{dl}$.

\section{$\mathrm{A} / \mathrm{G}$ ratio}

Serum A/G ratio was estimated by dividing albumin to globulin value.

\section{Serum alanine amino transferase (ALT)}

Serum ALT concentration was determined by 2, 4-DNPH method of Reitman and Frankel (1957), using a kit from Erba diagnostics. The concentration of ALT was expressed in IU/l.

\section{Aspartate amino transferase (AST)}

Serum AST concentration was determined by a modified Reitman Frankel's method explained by Reitman and Frankel (1957), using a kit from Erba diagnostics and the concentration of AST was expressed in IU/l.

\section{Serum alkaline phosphatase (ALP)}

Serum ALP concentration was determined by the method described by Wilkinson and Winsten (1969), using Transasia Biochemicals (Erba diagnostics) reagent kit and results were expressed in IU/l.

\section{Gamma Glutamyl Transferase (GGT)}

Serum GGT concentration was determined by the method described by Szasz method (Szasz, 1976).

\section{Diagnosis}

\section{Radiological examination}

Lateral Radiographs of dogs were taken for confirming the presence of ascitic fluid. This included any abnormalities in the shape and size in the abdomen Johnson (1992) noticed that the abdominal radiographs were rarely useful in significant ascites beyond confirming the presence of fluid because the loss of abdominal contrast indistinct all details ("ground glass appearance") (Bray, 1996 and Hall, 2005) in dogs with micro-hepatic cirrhosis. Plain film radiograph was obtained using $60 \mathrm{~mA}$ mobile machines (Allengers Medical System Ltd, Chandigarh). 


\section{Ultrasonography}

Ultrasonography imaging of dogs selected on the basis of clinical signs was performed as per the procedure described by Nyland and Mattoon (2014).

\section{Therapeutic Management}

The present study was undertaken on randomly selected 18 cases of ascitic dogs which were presented to the Teaching Veterinary Hospital of the College with the history of abdominal distension, anorexia, respiratory distress, dehydration, pale mucous membrane, diarrhoea and vomition. Each dog was subjected to the detailed clinical examination as per standard procedures. On the basis of clinical signs and hemato-biochemical and ultrasonographic examination, the dogs were diagnosed to be suffering with ascites due to liver dysfunction.

Total 18 ascitic dogs were divided in 3 groups, each contains 6 dogs. Group II, ascitic dogs were treated with standard therapy of Silymarin (syrup silytek) @ $25 \mathrm{mg} / \mathrm{kg}$ body weight orally two times a day daily for 45 days to modulating immune system and act as hepatoproctectant. Group III were treated with syrup Hepatocare @ 1-2 TSF orally twice a day for 45 days. It acts as an appetiser and digestive stimulant. Dogs of group IV were treated with syrup alfalfa @ 1-2 TSF orally 2 times a day that for 45 days acts as a digestive stimulant.

Supporting therapy was same in all the three groups comprised of tab furosemide (lasix) @ $2 \mathrm{mg} / \mathrm{kg}$ body weight orally once a day for 45 days (act as diuretic agent), syrup haem up @ 1-2 TSF orally twice daily for 45 days (used in preventing and treating anemia) and power protenix @ 1-2 TSF orally twice daily for 45 days (act as protein supplement).

\section{Statistical analysis}

The data were analyzed as per standard methods by Snedecor and Cochran (1994), to observed statistically significant differences within a group and in between the groups.

\section{Results and Discussions}

\section{Haematological profile}

\section{Haemoglobin (g/dl)}

The mean $\mathrm{Hb}$ values were significantly $(\mathrm{P} \leq 0.05)$ reduced in groups II, III and IV $(8.23 \pm 0.48, \quad 6.57 \pm 0.47$ and $6.97 \pm 0.51$ $\mathrm{g} /$ dlrespectively) when compared with healthy control G I (12.63 \pm 0.37$)$ on 0 day. After 15 days treatment, $\mathrm{Hb}$ concentration in all the groups showed improvement but in group II value was higher than other two groups. On day 30 and 45, there was no significant difference between groups III and IV, however, in group II improvement in $\mathrm{Hb}$ was significantly higher. The $\mathrm{Hb}$ values were comparatively higher in animals of group II as compared to treatment groups III and IV at respective time intervals (Table.1).

\section{Packed Cell Volume (\%)}

There was significant reduction in PCV values in groups II, III and IV $(35.50 \pm 1.62$, $31.00 \pm 2.04$ and $28.50 \pm 2.19 \%$ respectively) as compared to healthy control group G I $(42.00 \pm 1.81 \%)$ on day 0 but at $15^{\text {th }}$ day mean values of PCV increase in all three groups. However in group II, mean value was significantly higher than other two groups. In groups III and IV, mean values of group III was higher than group IV but lesser than group II. On days 30 and 45, mean values of all the three treatment groups shown improvement as compared with $15^{\text {th }}$ day but group II revealed better 
improvement in PCV values than other groups on day 45 (Table.1).

\section{Lymphocyte (\%)}

There was significant decrease in lymphocyte count in all three groups G II, G III, G IV $(24.17 \pm 0.96, \quad 24.83 \pm 2.11, \quad 24.17 \pm 1.43 \%$ respectively) at 0 day as compared to healthy group G I (27.33 $\pm 1.22 \%)$. On day 15 , values of all groups showed improvement and no significant difference was found up to last day of treatment in all the groups (Table.1).

\section{TEC (million/ $\mu \mathrm{l})$}

There was significant decrease in TEC values in all three groups G II, G III and G IV $(3.83 \pm 0.21, \quad 4.10 \pm 0.07$ and $4.05 \pm 0.34$ million/ $\mu \mathrm{l}$ ) as compared to healthy group $\mathrm{G} \mathrm{I}$ $(5.73 \pm 0.14 \mathrm{million} / \mu \mathrm{l})$ on day 0 .

Increment in TEC was observed after treatment. On day 15 and 30, no significant difference was found between treatment groups. On day 45, mean value of group II revealed better improvement than other two groups (Table.1).

\section{Biochemical parameters}

\section{ALT (IU/L)}

There was significant increase in ALT mean value of groups $G$ II, G II and G IV $(133.83 \pm 5.09, \quad 131.00 \pm 2.90 \quad$ and $130.02 \pm 4.18 \mathrm{IU} / 1$ respectively) as compared to control group (59.00 $\pm 2.62 \mathrm{IU} / \mathrm{l})$ on 0 day. After treatment, significant decrease was noticed in all groups. On day 15 and 30, significant difference was found in G II mean value as compared to other two treatment groups. On day 45, all group values reached to almost normal comparable value of healthy group but improvement was higher in group II (Table 1).

\section{$\operatorname{AST}($ IU/L)}

The values of ALT were significantly increased in all the 3 groups G II, G III and G IV $(130.17 \pm 3.24, \quad 131.00 \pm 4.45 \quad$ and $128.67 \pm 4.37 \mathrm{IU} / 1$ respectively) as compared to control group G I (56.17 $\pm 2.09 \mathrm{IU} / \mathrm{l})$ on 0 day. After treatment, there was significantly decrease in ALT values of all the three groups. On day 15, mean value of G I group was lower than other two treatment groups. On day 30, values in G II and G III groups were almost same and lower than group IV. Higher improvement was noticed in G II group from 0 to 45 day as compared to other groups (Table.1).

\section{$\operatorname{ALP}($ IU/L)}

Mean values of G II, G III and G IV groups $(192.83 \pm 5.50, \quad 180.17 \pm 7.15 \quad$ and $182.50 \pm 3.52 \mathrm{IU} / 1$ respectively) were found to be significantly higher when compared with healthy dogs of group G I (67.50 2 .69IU/1) on 0 day. Values of ALP in all three treatment groups were significantly decreased after treatment. On day, 15 and 30 , values in groups III and IV were almost same and higher than group II. On $45^{\text {th }}$ day, values in groups II and III reached to mean value of control group (Table.1).

\section{Total protein (g/dl)}

On day 0 mean value of total protein was significantly higher in control group $G$ I $(6.73 \pm 0.26 \mathrm{~g} / \mathrm{dl})$ than other three groups G II, G III and G IV $(4.83 \pm 0.18,4.59 \pm 0.22$ and $4.78 \pm 0.21 \mathrm{~g} / \mathrm{dl})$. After treatment, mean values of all three groups were increases.

On day 15 , no significant change was found in all the three treatment groups. On day 30, higher improvement was observed in group IIthan other groups. At last day of treatment, group II revealed better results followed by 
groups III and III when compared with 0 day (Table.2).

\section{Albumin}

There was significant decrease in mean values of albumin in all three groups G II, G III and G IV $(2.31 \pm 0.15,2.23 \pm 0.10$ and $2.37 \pm 0.15 \mathrm{~g} / \mathrm{dl}$ ) as compared to its value in control group G I (3.41 \pm 0.09$)$ on 0 day.

Values of albumin increased on $15^{\text {th }}$ day in all the three treatment groups but significant increment was observed in group IIthan groups III and IV. On day 30 and 45, no significant difference was observed in all three treatment groups but better results were found in group II (Table.2).

\section{Globulin (g/dl)}

Mean value of globulin in control group $G$ I $(3.32 \pm 0.11 \mathrm{~g} / \mathrm{dl})$ was significantly higher than other groups G II, G III and G IV (2.52 \pm 0.09 , $2.36 \pm 0.08$ and $2.41 \pm 0.09 \mathrm{~g} / \mathrm{dl}$ ) on 0 day. During the therapeutic study, significant improvements were seen in all the treatment groups.

After conclusion of treatment, globulin level in group IV was found to be significantly lower as compared to other groups (Table.2).

\section{A:G Ratio}

On day 0 , mean values of $A: G$ ratio in $\mathrm{G}$ II, $\mathrm{G}$ III and G IV $(0.91 \pm 0.04,0.94 \pm 0.04$ and $0.98 \pm 0.05)$ were significantly lower as compared to $\mathrm{G}$ I group (1.02 \pm 0.03$)$. On day $15, \mathrm{~A}: \mathrm{G}$ ratio was higher in groups $\mathrm{G}$ III than $\mathrm{G}$ II and G IV.

Its ratio on $30^{\text {th }}$ day of trial was highest for group G II followed by G III and G IV. At the conclusion of trial, A:G ratio in G II and G III were found almost similar to the healthy control group whereas in G IV, A:G ratio was lower than that in healthy dogs (Table.2).

\section{GGT (IU/L)}

There was significant increase in mean values of GGT in G II, G III and G IV (18.67 \pm 0.54 , $16.83 \pm 0.66$ and $17.17 \pm 0.52 \mathrm{IU} / \mathrm{l})$ groups as compared to healthy group G I (11.33 $\pm 0.54 \mathrm{IU} / \mathrm{l})$ on 0 day. On day 15, 30 and 45, no significant difference was observed in groups G III and G IV whereas in group II values were lower than other two treatment groups. From day 0 to 45, better improvement was seen in group II (Table.2).

\section{BUN (mg/dl)}

Mean values of BUN in groups G II, G III and $\mathrm{G} \quad \mathrm{IV} \quad(33.00 \pm 1.38, \quad 27.93 \pm 1.00$ and $35.27 \pm 1.85 \mathrm{mg} / \mathrm{dl}$ ) were significantly higher as compared to control group $\mathrm{G}$ I value $(19.52 \pm 0.60 \mathrm{mg} / \mathrm{dl})$ on day 0 . On day 15 , no significant difference was observed in groups G III and G IV whereas in group II, BUN level was lower than other two treatment groups. On day 30, no major difference was found in groups G II, G IV and control group whereas in group III values were considerably higher than other groups. No significant difference in all groups was recorded on day 45 (Table.2).

\section{Creatinine (mg/dl)}

There was significant increase in mean values of creatinine in groups II, III and IV $(1.55 \pm 0.05,1.45 \pm 0.05$ and $1.67 \pm 0.05 \mathrm{mg} / \mathrm{dl})$ as compared to control group G1 $(0.80 \pm 0.04 \mathrm{mg} / \mathrm{dl})$ on 0 day. No major difference was observed in groups G II and G III whereas group IV value was higher than other groups at $15^{\text {th }}$ day. On day 30 , no significant difference was noticed in groups $G$ II, G III and control group but value of group IV was higher than other groups. At the end of 
treatment values of creatinine in all the groups were almost same (Table.2).

\section{Radiography}

In radiological examination, all the ascitic dogs showed loss of abdominal details due to presence of fluid. There was ground glass appearance of the abdomen.

\section{Ultrasonographic Imaging}

In case of healthy dogs, abdominal ultrasonography did not show any abnormality in the organs present in the abdomen.

Normal liver parenchyma showed uniformly granular echotexture and in it pear shaped, anechoic vesicular gall bladder and walled portal veins were clearly visible. Healthy liver was found slightly more echogenic as compared to the kidney cortex but less echogenic than spleen.

On day 0, all ascitic dogs showed anechoic abdominal contents with diffused hyperechoic bright liver. Some dogs showed focal hyper echogenicity and hyperechoic small liver with irregular margins suggesting liver cirrhosis.

Dogs of groups, III and IV showed small amount of fluid surrounding liver and there was slight improvement in the echogenicity of liver parenchyma and decreased gall bladder distension at the end of treatment. In group II comparatively less amount of ascitic fluid was detected and normal echo texture of liver with normal gall bladder were observed as compared with groups III and IV. USG examination revealed better improvement in dogs of group II over the other groups.

Kashiide et al., (2014); Saravanan et al., (2014) also observed during abdominal ultrasonography, presence of anechoic to hypoechoic areas indicative of free-floating fluid in abdominal cavity. Caudal lobe of liver showed hyperechoic foci indicative of hepatic involvement in development of ascites. Kidneys did not show any ultrasonographic changes. There was presence of anechoic (black) free floating abdominal fluid.

Hoque and Varshney (2001) noticed diffuse hyper-echoic bright echo structure with prominent vasculature in cirrhosis. Nyland and Hager (1985) observed that normal liver parenchyma produced a uniform echo pattern except for vascular structure. Barr (1988) found normal liver as relatively echolucent with an even coarse white stippling due to multiple echoes from fibrous component.

Ultrasonography is useful in evaluating the parenchymal structure of the liver in animals and therefore, it can be an important technique to evaluate diffuse parenchymal disease of the liver (Cartee, 1981 and Nyland and Hager, 1985).

It is a non-invasive imaging technique and useful in the evaluation of liver parenchyma abnormality, hepatic vessel current characteristics, flow velocity and patterns (Bradley and Meredith, 1989).

\section{Therapeutic management}

The dogs treated with silymarin along with supportive therapy, responded well on $15^{\text {th }}$ day of treatment and attained its normal activities after 45 days, indicating better efficacy of silymarin against ascites due to hepatic dysfunction.

Clinical signs like abdominal distension, inappetance, pale mucous membrane, lethargy etc. were also improved in case of silymarin treated dogs. These findings are in accordance with the observations of earlier workers (Salmi and Sarna, 1982; Hruby et al., 1983; Ferenci et al., 1988; Trinchet et al., 1989; 
Parés et al., 1998). Worldwide, Silybummarianumis presently the plant on which most studies have been carried out in relation to the treatment of liver diseases. Benda and Zenz (1974) also reported that Silymarin seems to influence the liver function by stabilization of hepatocellular membrane, regeneration of hepatocytes and protection of the organ.

Kidd and Head (2005) stated thatmain ingredients in silymarin include silibinin, isosilibinin, silicristin and silidianin. Silymarin is an herbal therapy for chronic liver diseases worldwide.

Silibinin is the most important active compound in silymarin, which has been widely considered for its hepatoprotective effects and anti-cancer effects both in vitro and in vivo. In recent times, some modified forms of silymarin, such as the siliphos, have been developed for liver disease treatment.

This latest chemically synthesized agent included lecithin which can significantly improve the solubility and bioavailability of silymarin.

Silybinin, which is also recognized as silybin, exhibits antioxidant effect and induces mitochondrial biogenesis in cirrhotic liver (Serviddio et al., 2014). Silybinin can prevent the production of mitochondrial reactive oxygen species (ROS) and reduces the cardiolipin oxidation or citrate carrier failure in the liver of cirrhosis rat model.

Silybinin also exhibits anti-inflammatory effect in cirrhotic rat liver by decreasing the expression of lysophosphatidylcholine acyltransferase (LPCAT) although increasing platelet-activation factor level (Stanca et al., 2013). A clinical survey indicated that silymarin can reduce symptoms and signs in cirrhosis patients. Long-term use of silymarin may provide benefits to patients with chronic Hepatitis C (Seeff et al., 2008).

Medicines like silymarin (Sude et al., 2008) and choline have been proved as hepatoprotective and hepato-regenerative properties. Thyagarajan et al., (2002) stated that the Sylibummarianum has the actions of antioxidative, anti-lipid per oxidative, anti fibrosis, anti-inflammatory, immune-stimulate and liver regenerative capacity.

Saller et al.,(2001) noticed that Silymarin is the active component of milk thistle and it have antioxidant and free radical scavenging properties and is useful for various types of liver diseases, as well as protective agent against various hepatotoxicities. There are currently limited clinical studies evaluating its efficacy in dogs with liver disease. Suggested doses range from 50 to $250 \mathrm{mg} /$ day (Twedt, 2004).

Hepatocare treated group also showed good results on $15^{\text {th }}$ day and subsequent days of treatment but improvement was less as compared to the silymarin treated dogs.

Syrup hepatocare included vitamin $\mathrm{B}_{12}$, inositol, selenium, vitamin E, biotin, tricholine citrate and methyl donor.

Vitamin E was given as an antioxidant to eliminate free radicals and prevent oxidative injury to the liver. Vitamin E was preferred, since the absorption of fat soluble vitamins can be reduced in some types of liver diseases generally in case of hepatic origin (Deepak et al., 2015). Tricholine citrate acts as lipotropic agent and helps to remove excessive fat from the liver as well as prevents unnecessary fat deposition in the liver (Canty and Zeisel, 1994). Inositol is necessary for development of blood cells in the bone marrow, eye membranes and intestines (Levine et al., 1995). 
Table.1 Haemato- biochemical alterations in healthy and ascitic dogs at different time intervals (Mean \pm S.E.)

\begin{tabular}{|c|c|c|c|c|c|c|c|c|}
\hline DAY & GROUP & Hb (g/dl) & PCV (\%) & $\begin{array}{c}\text { Lymphocyte } \\
(\%)\end{array}$ & $\begin{array}{c}\text { TEC } \\
\text { (Million/ul) }\end{array}$ & ALT (IU/L) & AST (IU/L) & ALP (IU/L) \\
\hline \multirow{4}{*}{$\begin{array}{c}\mathbf{0} \\
\text { DAY }\end{array}$} & G I & $12.63 \pm 0.37^{\mathrm{aA}}$ & $42.00 \pm 1.81^{\mathrm{aA}}$ & $27.33 \pm 1.22^{\mathrm{aA}}$ & $5.73 \pm 0.14^{\mathrm{aA}}$ & $59.00 \pm 2.62^{\mathrm{bA}}$ & $56.17 \pm 2.09^{\mathrm{cA}}$ & $67.50 \pm 2.69^{\mathrm{cA}}$ \\
\hline & G II & $8.23 \pm 0.48^{\mathrm{bC}}$ & $35.50 \pm 1.62^{\mathrm{bB}}$ & $24.17 \pm 0.96^{\mathrm{bB}}$ & $3.83 \pm 0.21^{\mathrm{cC}}$ & $133.83 \pm 5.09^{\mathrm{aA}}$ & $130.17 \pm 3.24^{\mathrm{aA}}$ & $192.83 \pm 5.50^{\mathrm{aA}}$ \\
\hline & G III & $6.57 \pm 0.47^{\mathrm{cC}}$ & $31.00 \pm 2.04^{\mathrm{cC}}$ & $24.83 \pm 2.11^{\mathrm{bB}}$ & $4.10 \pm 0.07^{\mathrm{bA}}$ & $131.00 \pm 2.90^{\mathrm{aA}}$ & $131.00 \pm 4.45^{\mathrm{aA}}$ & $180.17 \pm 7.15^{\mathrm{abA}}$ \\
\hline & G IV & $6.97 \pm 0.51^{\mathrm{cC}}$ & $28.50 \pm 2.19^{\mathrm{dB}}$ & $24.17 \pm 1.43^{\mathrm{bB}}$ & $4.05 \pm 0.34^{\mathrm{bA}}$ & $130.02 \pm 4.18^{\mathrm{aA}}$ & $128.67 \pm 4.37^{\mathrm{abA}}$ & $182.50 \pm 3.52^{\mathrm{aA}}$ \\
\hline \multirow{4}{*}{$\begin{array}{c}15 \\
\text { DAY }\end{array}$} & G I & $12.47 \pm 0.34^{\mathrm{aA}}$ & $42.50 \pm 1.54^{\mathrm{aA}}$ & $27.50 \pm 1.46^{\mathrm{aA}}$ & $5.40 \pm 0.17^{\mathrm{aA}}$ & $58.50 \pm 2.40^{\mathrm{cA}}$ & $57.10 \pm 1.74^{\mathrm{dA}}$ & $67.67 \pm 2.17^{\mathrm{cA}}$ \\
\hline & G II & $10.35 \pm 0.78^{\mathrm{bB}}$ & $40.33 \pm 2.22^{\mathrm{aA}}$ & $27.33 \pm 0.92^{\mathrm{aA}}$ & $4.94 \pm 0.15^{\mathrm{bB}}$ & $73.50 \pm 2.72^{\mathrm{bB}}$ & $70.67 \pm 1.19^{\mathrm{cB}}$ & $82.17 \pm 2.95^{\mathrm{bB}}$ \\
\hline & G III & $7.67 \pm 0.26^{\mathrm{cC}}$ & $35.67 \pm 1.67^{\mathrm{bB}}$ & $27.00 \pm 1.77^{\mathrm{aA}}$ & $4.67 \pm 0.21^{\mathrm{bA}}$ & $84.83 \pm 1.07^{\mathrm{aB}}$ & $75.83 \pm 1.84^{\mathrm{bB}}$ & $88.83 \pm 4.48^{\mathrm{aB}}$ \\
\hline & G IV & $7.65 \pm 0.37^{\mathrm{cC}}$ & $31.50 \pm 1.62^{\mathrm{cA}}$ & $27.17 \pm 1.53^{\mathrm{aA}}$ & $4.30 \pm 0.29^{\mathrm{bA}}$ & $86.67 \pm 2.31^{\mathrm{aB}}$ & $82.50 \pm 2.40^{\mathrm{aB}}$ & $88.00 \pm 3.01^{\mathrm{aB}}$ \\
\hline \multirow{4}{*}{$\begin{array}{c}30 \\
\text { DAY }\end{array}$} & G I & $12.40 \pm 0.32^{\mathrm{aA}}$ & $42.30 \pm 1.73^{\mathrm{aA}}$ & $27.21 \pm 1.20^{\mathrm{aA}}$ & $5.52 \pm 0.12^{\mathrm{aA}}$ & $58.30 \pm 2.21^{\mathrm{cA}}$ & $56.35 \pm 2.12^{\mathrm{cA}}$ & $67.25 \pm 2.45^{\mathrm{bA}}$ \\
\hline & G II & $10.95 \pm 0.81^{\mathrm{bB}}$ & $40.78 \pm 1.73^{\mathrm{aA}}$ & $27.41 \pm 1.10^{\mathrm{aA}}$ & $4.98 \pm 0.17^{\mathrm{bB}}$ & $65.35 \pm 2.35^{\mathrm{bBC}}$ & $68.34 \pm 1.11^{\mathrm{aB}}$ & $70.35 \pm 1.63^{\mathrm{bC}}$ \\
\hline & G III & $8.80 \pm 0.34^{\mathrm{cB}}$ & $36.92 \pm 1.42^{\mathrm{bBA}}$ & $27.21 \pm 1.68^{\mathrm{aA}}$ & $4.69 \pm 0.20^{\mathrm{bA}}$ & $77.21 \pm 2.14^{\mathrm{aBC}}$ & $68.67 \pm 1.31^{\mathrm{aBC}}$ & $78.25 \pm 2.63^{\mathrm{aBC}}$ \\
\hline & G IV & $8.94 \pm 0.43^{\mathrm{cB}}$ & $31.82 \pm 1.82^{\mathrm{cA}}$ & $27.31 \pm 1.51^{\mathrm{aA}}$ & $4.37 \pm 0.24^{\mathrm{bA}}$ & $77.10 \pm 3.18^{\mathrm{aBC}}$ & $70.57 \pm 2.86^{\mathrm{aBC}}$ & $78.54 \pm 2.72^{\mathrm{aB}}$ \\
\hline \multirow{4}{*}{$\begin{array}{c}45 \\
\text { DAY }\end{array}$} & G I & $12.43 \pm 0.33^{\mathrm{aA}}$ & $42.51 \pm 1.55^{\mathrm{aA}}$ & $27.51 \pm 1.47^{\mathrm{aA}}$ & $5.70 \pm 0.19^{\mathrm{aA}}$ & $58.75 \pm 2.45^{\mathrm{aA}}$ & $57.12 \pm 1.85^{\mathrm{abA}}$ & $67.21 \pm 2.41^{\mathrm{aA}}$ \\
\hline & GII & $12.34 \pm 0.78^{\mathrm{aA}}$ & $41.85 \pm 2.10^{\mathrm{aA}}$ & $27.42 \pm 0.97^{\mathrm{aA}}$ & $5.73 \pm 0.18^{\mathrm{aA}}$ & $54.10 \pm 1.59^{\mathrm{aC}}$ & $56.20 \pm 1.04^{b C}$ & $65.33 \pm 2.06^{\mathrm{aC}}$ \\
\hline & GIII & $10.35 \pm 0.24^{\mathrm{bA}}$ & $38.20 \pm 1.13^{\mathrm{bA}}$ & $27.40 \pm 1.73^{\mathrm{aA}}$ & $4.83 \pm 0.21^{\mathrm{bA}}$ & $58.73 \pm 1.56^{\mathrm{aC}}$ & $59.32 \pm 1.20^{\mathrm{aBC}}$ & $67.51 \pm 1.64^{\mathrm{aC}}$ \\
\hline & GIV & $10.03 \pm 0.49^{\mathrm{bA}}$ & $32.34 \pm 1.41^{\mathrm{cA}}$ & $27.38 \pm 1.33^{\mathrm{aA}}$ & $4.50 \pm 0.27^{\mathrm{bA}}$ & $61.30 \pm 1.13^{\mathrm{aC}}$ & $59.53 \pm 1.35^{\mathrm{aBC}}$ & $69.43 \pm 1.81^{\mathrm{aB}}$ \\
\hline
\end{tabular}

Mean values bearing same superscript in a column (a, b, c, d) and row (A, B, C, D) differ significantly (p $\leq 0.05)$. 
Table.2 Biochemical alterations in healthy and ascitic dogs at different time intervals (Mean \pm S.E.)

\begin{tabular}{|c|c|c|c|c|c|c|c|c|}
\hline DAY & GROUP & $\underset{(\mathrm{g} / \mathrm{dl})}{\mathbf{T P}}$ & $\begin{array}{c}\text { Albumin } \\
(\mathrm{g} / \mathrm{dl})\end{array}$ & $\begin{array}{l}\text { Globulin } \\
\text { (g/dl) }\end{array}$ & A:G Ratio & $\begin{array}{c}\text { GGT } \\
\text { (IU/L) }\end{array}$ & $\begin{array}{c}\text { BUN } \\
\text { (mg/dl) }\end{array}$ & $\begin{array}{c}\text { Creatinine } \\
\text { (mg/dl) }\end{array}$ \\
\hline \multirow[t]{4}{*}{ O DAY } & G I & $6.73 \pm 0.26^{\mathrm{aA}}$ & $3.41 \pm 0.09^{\mathrm{aA}}$ & $3.32 \pm 0.11^{\mathrm{aA}}$ & $1.02 \pm 0.03^{\mathrm{aA}}$ & $11.33 \pm 0.54^{\mathrm{cA}}$ & $19.52 \pm 0.60^{\mathrm{cA}}$ & $0.80 \pm 0.04^{\mathrm{cA}}$ \\
\hline & G II & $4.83 \pm 0.18^{\mathrm{bC}}$ & $2.31 \pm 0.15^{\mathrm{cB}}$ & $2.52 \pm 0.09^{\mathrm{bB}}$ & $0.91 \pm 0.04^{\mathrm{bB}}$ & $18.67 \pm 0.54^{\mathrm{aA}}$ & $33.00 \pm 1.38^{\mathrm{aA}}$ & $1.55 \pm 0.05^{\mathrm{aA}}$ \\
\hline & G III & $4.59 \pm 0.22^{\mathrm{bB}}$ & $2.23 \pm 0.10^{\mathrm{cB}}$ & $2.36 \pm 0.08^{\mathrm{bB}}$ & $0.94 \pm 0.04^{\mathrm{bB}}$ & $16.83 \pm 0.66^{\mathrm{bA}}$ & $35.27 \pm 1.85^{\mathrm{aA}}$ & $1.45 \pm 0.05^{\mathrm{bA}}$ \\
\hline & G IV & $4.78 \pm 0.21^{\mathrm{bB}}$ & $2.37 \pm 0.15^{\mathrm{cB}}$ & $2.41 \pm 0.09^{\mathrm{bA}}$ & $0.98 \pm 0.05^{\mathrm{bB}}$ & $17.17 \pm 0.52^{\mathrm{abA}}$ & $27.93 \pm 1.00^{\mathrm{bA}}$ & $1.67 \pm 0.05^{\mathrm{aA}}$ \\
\hline \multirow{4}{*}{$\begin{array}{c}15 \\
\text { DAY }\end{array}$} & GI & $6.73 \pm 0.13^{\mathrm{aA}}$ & $3.40 \pm 0.10^{\mathrm{aA}}$ & $3.33 \pm 0.13^{\mathrm{aA}}$ & $1.02 \pm 0.04^{\mathrm{aA}}$ & $11.00 \pm 0.40^{\mathrm{cA}}$ & $19.35 \pm 0.48^{\mathrm{cA}}$ & $0.87 \pm 0.08^{\mathrm{cA}}$ \\
\hline & GII & $5.42 \pm 0.17^{\mathrm{bB}}$ & $2.68 \pm 0.08^{\mathrm{bAB}}$ & $2.74 \pm 0.06^{\mathrm{bB}}$ & $0.97 \pm 0.05^{\mathrm{bB}}$ & $13.17 \pm 0.52^{b B}$ & $26.08 \pm 1.25^{\mathrm{bB}}$ & $1.20 \pm 0.03^{\mathrm{bB}}$ \\
\hline & GIII & $5.04 \pm 0.22^{\mathrm{bB}}$ & $2.53 \pm 0.10^{\mathrm{bB}}$ & $2.51 \pm 0.08^{\mathrm{bB}}$ & $1.00 \pm 0.03^{\mathrm{aA}}$ & $14.17 \pm 0.66^{\mathrm{aB}}$ & $28.45 \pm 1.31^{\mathrm{aB}}$ & $1.18 \pm 0.07^{\mathrm{bB}}$ \\
\hline & GIV & $5.11 \pm 0.27^{\mathrm{bA}}$ & $2.48 \pm 0.15^{\mathrm{bB}}$ & $2.63 \pm 0.08^{\mathrm{bA}}$ & $0.94 \pm 0.04^{\mathrm{bB}}$ & $14.50 \pm 0.37^{\mathrm{aB}}$ & $24.38 \pm 0.40^{\mathrm{bB}}$ & $1.45 \pm 0.02^{\mathrm{aB}}$ \\
\hline \multirow{4}{*}{$\begin{array}{c}30 \\
\text { DAY }\end{array}$} & GI & $6.75 \pm 0.35^{\mathrm{aA}}$ & $3.40 \pm 0.13^{\mathrm{aA}}$ & $3.35 \pm 0.09^{\mathrm{aA}}$ & $1.01 \pm 0.05^{\mathrm{aA}}$ & $11.23 \pm 0.43^{\mathrm{bA}}$ & $19.23 \pm 0.40^{\mathrm{bA}}$ & $0.86 \pm 0.06^{\mathrm{bA}}$ \\
\hline & GII & $5.94 \pm 0.21^{\mathrm{abB}}$ & $3.00 \pm 0.13^{\mathrm{aA}}$ & $2.94 \pm 0.11^{\mathrm{bB}}$ & $1.02 \pm 0.04^{\mathrm{aA}}$ & $11.76 \pm 0.64^{\mathrm{bBC}}$ & $20.31 \pm 1.10^{\mathrm{bC}}$ & $0.93 \pm 0.07^{\mathrm{bC}}$ \\
\hline & GIII & $5.62 \pm 0.12^{b B}$ & $2.82 \pm 0.14^{\mathrm{aB}}$ & $2.80 \pm 0.06^{\mathrm{bB}}$ & $1.00 \pm 0.07^{\mathrm{aA}}$ & $13.27 \pm 0.52^{\mathrm{aB}}$ & $23.83 \pm 1.27^{\mathrm{aC}}$ & $1.00 \pm 0.08^{\mathrm{bBC}}$ \\
\hline & GIV & $5.57 \pm 0.24^{\mathrm{bA}}$ & $2.78 \pm 0.14^{\mathrm{aB}}$ & $2.79 \pm 0.05^{\mathrm{cA}}$ & $0.99 \pm 0.08^{\mathrm{aA}}$ & $13.73 \pm 0.38^{\mathrm{aB}}$ & $21.93 \pm 0.88^{\mathrm{bC}}$ & $1.13 \pm 0.03^{\mathrm{aC}}$ \\
\hline \multirow{4}{*}{$\begin{array}{c}45 \\
\text { DAY }\end{array}$} & GI & $6.74 \pm 0.34^{\mathrm{aA}}$ & $3.42 \pm 0.10^{\mathrm{aA}}$ & $3.32 \pm 0.10^{\mathrm{aA}}$ & $1.03 \pm 0.05^{\mathrm{aA}}$ & $11.21 \pm 0.41 \mathrm{aA}$ & $19.30 \pm 0.46^{\mathrm{aA}}$ & $0.87 \pm 0.06^{\mathrm{aA}}$ \\
\hline & GII & $6.77 \pm 0.15^{\mathrm{aA}}$ & $3.43 \pm 0.17^{\mathrm{aA}}$ & $3.30 \pm 0.10^{\mathrm{aA}}$ & $1.03 \pm 0.02^{\mathrm{aA}}$ & $11.31 \pm 0.53^{\mathrm{aC}}$ & $18.98 \pm 1.01^{\mathrm{aC}}$ & $0.86 \pm 0.05^{\mathrm{aC}}$ \\
\hline & GIII & $6.68 \pm 0.14^{\mathrm{aA}}$ & $3.40 \pm 0.16^{\mathrm{aA}}$ & $3.28 \pm 0.09^{\mathrm{aA}}$ & $1.03 \pm 0.03^{\mathrm{aA}}$ & $10.84 \pm 0.50^{\mathrm{bC}}$ & $21.62 \pm 1.25^{\mathrm{aC}}$ & $0.86 \pm 0.04^{\mathrm{aC}}$ \\
\hline & GIV & $5.98 \pm 0.28^{\mathrm{bA}}$ & $2.98 \pm 0.16^{\mathrm{aA}}$ & $2.97 \pm 0.12^{\mathrm{bA}}$ & $1.00 \pm 0.06^{\mathrm{aA}}$ & $10.58 \pm 0.41^{\mathrm{bC}}$ & $20.31 \pm 1.10^{\mathrm{aC}}$ & $0.92 \pm 0.07^{\mathrm{aC}}$ \\
\hline
\end{tabular}


Schwarz and Foltz (1957) reported that the trace amount of selenium in diet could protect rats against liver necrosis. The liver plays a very important role in the storage and bioavailability of vitamin B12 (Pflipsen et al., 2009). Several liver diseases such as acute hepatitis, alcoholic hepatitis, liver cirrhosis and hepatocellular carcinoma have been associated with alteration in plasma levels vitamin B12 by different pathways (Koplay et al., 2011; Cylwik et al., 2010).

Biotin is a vitamin which acts as a co-factor for several carboxylases that play significant roles in the synthesis of fatty acids, the catabolism of branched-chain amino acids and gluconeogenesis (Carlo et al., 2014). Obeid (2013) observed that methyl groups plays important role in protein synthesis and energy metabolism of liver.

Alfalfa treated group showed comparatively less improvement in clinical signs and biochemical parameter as compared to the other groups treated with silymarin or hepatocare.

Amraie et al.,(2015) recorded that alfalfa extract improved liver function and decreased the level of hepatic enzymes like AST and ALT.

Alfalfa leafs are good source of iron, calcium, magnesium, phosphorous, niacin, biotin, folic acid, potassium and vitamins (B, A, D, K). Its leaves contain chlorophyll and protein. Alfalfa utilized as a dietary or nutritional supplement. The benefits of alfalfa leaf include supporting good circulation and the immune system(Gaweł, 2012).

Clinical sings and vital parameters were improved after treatment in the all three groups but better improvement was observed in dogs which were treated with silymarin as compared to hepatocare and alfalfa treated groups. So based on the present study it can be concluded that silymarin has higher efficacy for therapeutic management of ascites in canines than the other two drugs.

The therapeutic efficiency of furosemide tablets is from the movement of the whole and unaltered molecule throughout the nephron, reducing the reabsorption of sodium in the proximal tubule, distal tubule and also in the ascending limb of the loop of Henle. The quick onset of action is a result of the drug's rapid absorption and poor lipid solubility. The less lipid solubility and a quick renal excretion minimize the chance of its accumulation in tissues and organs or crystalluria(Timmerman et al., 1964;Berman and Ebrahimi, 1965; Martindale, 1977).

\section{Haematological profiles}

These results are in accordance with Sharma et al., (2001) who stated thatliver apart from kidney is the organ which is involved in the secretion of erythropoietin and other factors required for erythropoiesis and thereby liver dysfunction leads to anaemia. Bush (2002) noticed that decrease in haemoglobin concentration is due to increased degradation of erythrocytes due to prolonged transit time through spleen because of decreased portal blood flow and/or increased fragility of erythrocytes due to high levels of bile acids. All these further impair bone marrow responses, decreased erythrocyte survival time and decreased nutrient uptake as a results of inappetance or anorexia and reduced availability of micronutrients from liver.

Highly significant $(\mathrm{p}<.05)$ difference in haemoglobin and PCV values was observed in ascitic dogs which indicated the presence of anaemia. Webster (2005) also mentioned anaemia in dog with hepatobiliary dysfunction. In case of ascites normocytic, normochromic, non-regenerative anaemia 
occurs due to chronic inflammatory disease or secondary to multiple factors which impair the DNA synthesis leading to maturation arrest of pro-rubricyte to rubricyte stage (Willard and Tvedten, 1999; Benjamin, 2010).

Nottidge et al., (2003) mentioned that decreased level of $\mathrm{Hb}, \mathrm{PCV}, \mathrm{RBC}$, lymphocytes and increased level of TLC and neutrophils are observed in liver cirrhosis and ascites in dogs (Parker, 2002; Pradhan et al., 2008).

Significantly lower values of TEC and lymphocytes and significantly higher TLC and neutrophils as compared to healthy animals occur in pathological conditions like infection, intoxication, acute haemolysis and neoplasia (Sharma et al., 2001; Benjamin, 2005).

\section{Biochemical parameters}

Duncan et al., (1977) stated that Persistent of high levels of serum glutamic-oxalacetic transminase (SGOT) and glutamic-pyruvate transaminase (SGPT) enzymes indicate hepatocellular damage and persistent high levels is suggestive of continuing damage. It is important to remember that the magnitude of the increase in enzyme levels is proportionate to the damage.

Hepato-cellular damage leads to elevated serum ALT activity (Sterczer et al., 2001). Three times more than the normal serum ALT level has been reported earlier in hepatic anoxia, hepatic perfusion, chronic hepatitis, liver cirrhosis, cholangitis and cholangiohepatitis (Willard and Tvedten, 1999).

De Novo and prasse (1983) noticed that highest AST level is associated with acute hepatic injury, but a moderate increase in chronic liver disease includes hepatocellular disease, cirrhosis, parasitic cause of hepatopathy and primary or metastatic neoplasia. Serum ALT and AST measurements have been found to be highly useful in detecting hepatocellular injury and observing clinical progress (Tennant and Center, 2008). Elevated plasma transaminases such as ALT and AST were indicative of altered permeability of hepatocellular membrane, hepatocellular necrosis and inflammation with degree proportional to the number of injured hepatocytes (Kramer and Hoffman, 1997).

Protein levels should be determined and a specific check for albumin levels should be analysed. Hypoalbuminemia rarely is the primary cause of ascites but definitely contributes to the continuation to cause ascites the albumin level must be less than $1.5 \mathrm{~g} / \mathrm{dl}$. Decreased hepatic synthesis contributes to hypoalbuminemia but a more probable cause is expansion of the plasma volume and subsequent dilution of albumin (Duncan and Prasse, 1977; Strombeck, 1979). In addition to failure of hepatocyte synthetic capability, other factors may contribute to hypoalbuminemia in animals with liver failure (Doweiko and Nompleggi, 1991).

Hypoalbuminemia occurs due to low synthesis or higher loss of albumin, redistribution of albumin outside the intravascular space and dilution of albumin inside intravascular space. Many factors influence albumin synthesis, but most common are liver failure, inflammation and malnutrition. Since liver is the primary site of albumin synthesis, hepatic failure of more than $75 \%$ can result in hypoalbuminemia (Mazzaferro et al., 2002). Liver is the primary site for the synthesis of major plasma proteins as well as site of synthesis and degradation of many other proteins therefore these are influenced by liver diseases in many ways (Webster, 2005). Ascites causes high level of albumin distribution and lowering the blood albumin concentration leading to decrease in 
plasma osmotic pressure and aggravates the formation of ascitic fluid (Richter, 2003; Tennant and Center, 2008).

A:G ratio of 0.66 denoted acute hypoalbuminic ascites in dogs. Hypoalbuminemia results from albumin loss, decreased production or inflammatory conditions (Center, 1989; Parker, 2002).

Markedly increased activity of GGT, ALP, bile acids, bilirubin with prolong PT, aPTT and activated clotting time have earlier been reported in cholangitis, cholecystitis and biliary rubture (Johnson and Sherding, 1994; Nelson and Couto, 1996).

Sampaio et al., (2014) reported that renal dysfunction is a frequent complication in patients with end stage liver disease. Hence, increased BUN and creatinine values could be attributed to impaired kidney function associated with liver cirrhosis due to the decreased capacity of liver to detoxify the harmful products.

HRS (hepato-renal syndrome) occurs with complex liver cirrhosis and characterized by marked decrease in glomerular filtration rate (GFR) and renal plasma flow (RPF) in the absence of other causes of renal failure. The characteristic of HRS is severe renal vasoconstriction with major peripheral arterial vasodilation. Tubular function is preserved with the lack of histological changes or proteinuria in the kidney. Two subtypes of HRS have been recognized: Type 1 HRS is a quick progressive renal failure that is defined by doubling of initial serum creatinine to a level more than $2.5 \mathrm{mg} / \mathrm{dl}$ or by $50 \%$ drop in creatinine clearance to a level less than 20 $\mathrm{ml} / \mathrm{min}$ in less than two week (Iwatsuki et al., 1973).

The radiographic findings correlates with the observation made by Johnson (1992) who stated that the abdominal radiographs were rarely useful in diagnosing ascites beyond confirming the presence of fluid because the loss of abdominal contrast obstructs all details ("ground glass" appearance) in dogs with micro-hepatic cirrhosis (Bray, 1996 and Hall, 2005).

McGrothy and Doust (2004) observed that the abdominal radiographs may demonstrate a loss of contrast due to the presence of an effusion.

\section{References}

Amraie, E., Farsani, M.K., Sadeghi, L., Khan, T.N., Babadi, V.Y. and Adavi, Z. (2015).The effects of aqueous extract of alfalfa on blood glucose and lipids in alloxan-induced diabetic rats. Interv. Med. Appl. Sci.7(3): 124-128.

Banerjee, S. (2003). Significance of hepatic copper values in dogs with hepatitis. Thesis. M.V.Sc TANUVAS, Chennai.

Barr, F. (1998). The use of ultrasound in dog. Vet. Ann.28:136-145.

Benda, L. and Zenz, W. (1974). Long term outpatient treatment of hepatic cirrhosis. Therapiewoche. 24: 3598-3608.

Benjamin, M.M. (2005). Outline of veterinary

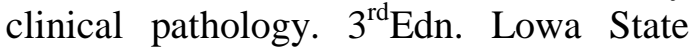
University Press.

Benjamin, M.M. (2010). Outline of veterinary clinical pathology. $3^{\text {rd }}$ edn. Kalyani publication, new delhi, pp: 127-136.

Berman, L.B. and Ebrahimi, A. (1965). Experiences with Furosemide in Renal Disease. Proc. Soc. Exp. Biol. Med. 118: 333-336.

Bonses, R.M. and Taussky, H.H. (1945). On colorimetric determination of creatinine by Jaffe reaction. J. Biol. Chem. 158: 581591.

Bradley, D.L. and Meredith, J. (1989). Current application of duplex and colourdoppler ultrasound imaging: abdomen. Mayo. Clin. Proc.64: 1158-1169.

Bray, J. (1996). Diagnosis and management of 
peritonitis in small animals. In practice, 18: 403-413.

Bush, B.M. (2002). Interpretation of laboratory results for small animal clinics. Blackwell Sciences Co, Lowa, USA. pp: 317-319.

Canty, D.J. and Zeisel, S.H. (1994). Lecithin and choline in human health and disease. Nutrition Reviews. 52(10): 327-339.

Carlo, A., Roberto, B. C., Susan, F., Marina, H., Hannu, K. and Sébastien L.V. (2014). Scientific opinion on dietary reference values for biotin. EFSA Journal.12(2): 3580 .

Cartee, R.E. (1981). Diagnostic real time ultrasonography of the liver of the dog and cat. J. Am. Anim. Hosp. 17: 731-737.

Center, S.A. (1989). Pathophysiology and laboratory diagnosis of liver disease. In: textbook of veterinary internal medicine. S.J. Ettinger (edt.), W.B. Saunders \& company, Philadelphia.

Cylwik, B., Czygier, M. and Daniluk, M. (2010). Vitamin B12 concentration in the blood of alcoholics. Pol MerkurLekarski. 28: 122-125.

De Novo, R.C. and Prasse, K.W. (1983). Comparison of serum biochemical and hepatic functional alteration in dogs treated with corticosteroids and hepatic duct ligation. Am. J. Vet. Res.44: 17031709.

Deepak M. K., Surendra, S.K., Mahabaleshwar, V.H. and Hanhong, B. (2015).Significance of Antioxidant Potential of Plants and its Relevance to Therapeutic Applications.Int. J. Biol. Sci.11(8): 982-991.

Doweiko, J.P. and Nompleggi, D.J. (1991). The role of albumin in human physiology and pathophysiology part $3^{\text {rd: }}$ albumin and disease state. J. Parenter. Enternal. Nutri. 15 (4): 476-483.

Duncan. J.R. and Prasse, K.W. (1977). Veterinary laboratory medicine-clinical pathology, ISU Press, Ames, I.A.

Duncan. J.R. and Prasse, K.W. (1977). Veterinary laboratory medicine-clinical pathology, ISU Press, Ames, I.A.

Ferenci, P., Dragosics, B. and Dittrich H. Kamble, M. B., Dumbre, R. K. and Rangari, V.
(1989). Randomized controlled trial of silymarin treatment in patients with cirrhosis of the liver. J. Hepatol.9(1): 105-113.

Fingerhunt, B., Ferzola, R., Marsh, W.H. and Miller, A.B. (1966). Automated methods for blood glucose and urea with adaptation for simultaneous determination. Clin. Chem. 12: 570-576.

Gaweł, E. (2012). Chemical composition of lucerne leaf extract (EFL) and its applications as a phytobiotic in human nutrition.Acta. Sci. Pol. Technol. Aliment. 11(3): 303-310.

Hall, E.J. (2005). Ascites. Manual of canine and BASAVA, Wood house. pp: 97-102.

Hoque, M. and Varshney, J.P. (2001).Ultrasonographic examination of hepatobiliary system in dogs: an analysis of 35 cases. Indian J. Vet. Med. 21: 76-81.

Hruby, K., Csomos, G., Fuhrmann, M. and Thaler, H. (1983). Chemotherapy of Amanita phalloides poisoning with intravenous silibinin. Human Toxicology. 2(2): 183-195.

Hunt, G.B. (2002). Abdominal condition of the dog and cat. In: $27^{\text {th }}$ WSAVA congress. Grananda, spain.

Iwatsuki, S., Popovtzer, M.M., Corman, J.L., Ishikawa, M., Putnam, C.W., Katz, F.H. and Starzl T.E. (1973). Recovery from "hepatorenal syndrome" after orthotropic liver transplantation. N. Engl. J. Med. 289: $1155-1159$.

Jain, N.C. (1986).Schalm's Veterinary Haematology, $4^{\text {th }}$ ed. Lea and Febiger, Philadelphia. pp: 103-110.

Johnson, S.E. (1992). Liver and biliary tract. In: Anderson, N.V, Lea and febiger. Eds. Veterinary gastroenterology $-2^{\text {nd }} \mathrm{edn}$. London. pp: 533-535.

Johnson, S.E. and Sherding, R.G. (1994). Diseases of the liver and biliary tract. In: Bichard, S.J. and Sherding, R.G. eds. Saunders Manual of small animal practice. W.B. Saunders, Philadelphia, pp: 723 724 feline gastroenterology. $\quad 2^{\text {nd }} \mathrm{edn}$. 
D. (2009). Hepatoprotective activity studies of herbal formulations. Greenpharmacy.2: 147-151.

Kashiide, T., Matsumoto, J., Yamaya, Y., Uwasawa, A., Miyoshi, A., Yamada, K., Watari, T. and Nogami, S. (2014). Care report: First confirmed case of canine peritoneal larval cestoidiasis caused by Mesocestoidesvogae (syn. M. corti) in Japan. Vet. Parasitol. 201(1-2):154-157.

Kidd, P. and Head, K. A. (2005). Review of the bioavailability and clinical efficacy of milk thistle phytosome: A silybinphosphatidylcholine complex (siliphos). Altern. Med. Rev. J. Clin. Ther. 10: 193-203.

Koplay, M., Gulcan, E. and Ozkan, F. (2011). Association between serum vitamin B12 levels and the degree of stenosis in patients with nonalcoholic fatty liver disease. J. Investig Med.59(7): 1137-1140.

Kramer, J.W. and Hoffman, W.E. (1997). Clinical enzymology. In: Clinical Biochemistry of Domestic Animals. Kaneko J, J Harvey and M Bruss, (eds) Academic Press London, pp: 330.

Levine. J., Barak, Y. and Kofman, O. (1995). Follow-up and relapse analysis of an inositol study of depression. Isr. $J$. Psychiatry Relat. Sci.32(1): 14-21.

Martindale, (1977).The Extra Pharmacopoeia. The Pharmaceutical Press, London, pp: 556.

Mazzaferro, E.M., Randloff, E. and Kirby, R. (2002). The role of albumin replacement in the critically ill veterinary patient. $J$. Vet. Emer. Crit. care.12(2): 113-124.

Mc Grothy, Y. and Doust, R. (2004). Management of peritionitis in dogs and cats. In practice, $\quad 26: 358-367$.

Nelson, R. W. and Couto, C. G. (1996). Diagnostic tests for the hepatobiliary system. In: small animal internal medicine. pp: 487-509.

Nyland, G.N. andMattoon, J.S. (2014). Small animal ultrasound, $3^{\text {rd }}$ edition saunderspublication, pp: 680 .

Nyland, T.G. and Hager, D.A. (1985). Sonography of the liver, gallbladder and spleen. Vet. Clin. North Am. (Small AnimPract). 15: 1123-1148.

Obeid,R. (2013). The metabolic burden of methyl donor deficiency with focus on the betaine homocysteine methyltransferase pathway.Nutrients.5(9): 3481-3495.

Ola EL-Segaey, Ahmad Ab-Allah and Saad Abu Al-Nooman. (2007). Experimental study of antioxidant and hepatoprotective effects of clove and cardamom in ethanol induced hepatoyoxicity. Tanta Med. Sci. J.2(1): 27-36.

Oser, B.L. (1976). Hawk's Physiological Chemistry. $14^{\text {th }}$ ed. New Delhi, TheBlactston Division, Mc Graw Hill Publishing Co Ltd.

Pares, A., Planas, R. And Torres M. (1998). Effects of silymarin in alcoholic patients with cirrhosis of the liver: results of a controlled, double-blind, randomized and multicenter trial. J. Hepatol.28(4): 615621.

Parker, M.D. (2002). An unusual cause of abdominal distension in dog. Vet. Med.97: 233-235.

Parker, M.D. (2002). An unusual cause of abdominal distension in dog. Vet. Med.97: 233-235.

Pflipsen, M.C., Oh, R.C., Saguil, A., Seehusen, D.A., Seaquist, D. and Topolski, R. (2009). The prevalence of vitamin $\mathrm{B}(12)$ deficiency in patients with type 2 diabetes: a cross- sectional study. J. Am. Board Fam. Med.22(5): 528-534.

Pradhan, M. S., Dakshinkar, N. P., Waghaye, U. G. and Bodkhe, A. M. (2008). Successful treatment of ascites of hepatic origin in dog. Veterinary World.1(1): 23.

Randhawa, S.S., Dhaliwal, P.S., Kirti, S., and Singh, K.B. (1988) Ind. J. Anim. Hlth., 12: 165.

Reitman, S. and Frankel, S. (1957). Colorimetric method for the determination of serum glutamic oxaloacetic and gutamic transaminases. Am. J. Clin. Path. 28: 5663.

Richter, K.P. (2003). Disease of the liver and hepato biliary system. In: Jam, T.R. ed. Hand book of small animal 
gastroenterology, $2^{\text {nd }}$ edn. St. Louish, Missouri: pp: 379-381.

Saller, R., Meier, R. and Brignoli, R. (2001). The use of silymarin in the treatment of liver diseases. Drugs. 61(14): 2035-2063.

Salmi, H. A. and Sarna, S. (1982). Effect of silymarin on chemical, functional and morphological alterations of the liver. A double-blind controlled study. Scand. J. Gastroenterol.17(4): 517-521.

Sampaio, M.S., Martin, P. and Bunnapradist, S. (2014). Dysfunction in end stage liver disease and post liver transplant. Clin. Liver Dis. 18(3): 543-560.

Saravanan, M., Mondal, D. B., Sharma, K., Mahendram, K. and Sasikala, V. (2014). Utility of Serum Ascites Albumin Gradient in $\operatorname{dogs}$ as indicator of hepatobiliary disorders induced ascites. Indian Vet. J.91(4): 33-35.

Saravanan, M., Sarma, K., Kumar, M., Mahendran, K., \&Mondal, D. B. (2013). Therapeutic Management of Ascites in Dogs. Indian Vet. J,90(2): 110-111.

Schalm, O.W., Jain, N.C. and Carroll, E.J. (1986). Veterinary haematology. $4^{\text {th }}$ ed. Lea and Febiger. Philadephia.

Schwarz, K. and Foltz, C. M. (1957). Se as an integral part of factor against dietary liver degeneration. J. Am. Chem. Society. 79: 3292-3296.

Seeff, L.B., Curto, T.M., Szabo, G., Everson, G.T., Bonkovsky, H.L., Dienstag, J.L., Shiffman, M.L., Lindsay, K.L., Lok A.S. and Di Bisceglie A.M. (2008). Herbal product use by persons enrolled in the hepatitis c antiviral long-term treatment against cirrhosis (halt-c)

Rothuizen, J. (2001). Chronic hepatitis in the dogs. A review. Vet. Q.32: 14-52.

Strombeck, D.K. (1979). Introduction to disease of the liver, In: small animal gastroenterology, stonegate publishing, Davis, CA.

Szasz, G. (1976). Reaction rate method for gamma glutamyl transferase activity in serum. Clin. Chem. 22: 2051-2056.

Tennant, B.C. and Center, S.A. (2008). Hepatic function In: Kaneko, J.J. Harvey, J.W. and trial. Hepatology. 47: 605-612.

Seiverd, C.E. (1983).Haematology for Medical Technologists. Lea and Febiger, Philadelphia, USA. 946p.

Serviddio, G., Bellanti, F., Stanca, E., Lunetti, P., Blonda, M., Tamborra, R., Siculella, L., Vendemiale, G., Capobianco, L. and Giudetti, A.M. (2014). Silybin exerts antioxidant effects and induces mitochondrial biogenesis in liver of rat with secondary biliary cirrhosis. Free Radic. Biol. Med.73: 117-126.

Sharma, M.C., Pathak, N.N. and Lai, S.B. (2001). In: liver-structure, diagnosis, disorders and therapeutic management. IVRI publication.

Sharma, M.C., Pathak, N.N. and Lai, S.B. (2001). In: liver-structure, diagnosis, disorders and therapeutic management. IVRI publication.

Snedecor, G.W. and Cochran, W.G. (1994). Statistical methods. 8. USA: Iowa State Univeristy Press.

Stanca, E., Serviddio, G., Bellanti, F., Vendemiale, G., Siculella, L. and Giudetti, A.M. (2013). Down-regulation of lpcat expression increases plateletactivating factor level in cirrhotic rat liver: Potential antiinflammatory effect of silybin. Biochim. Biophys. Acta.1832: 2019-2026.

Steiner, J.M. (2008). Laboratory test for the diagnosis of liver disease. In small animal gastroenterology, Schlutersche. pp: 57.

Sterczer, A., Gaal, T., Perge, E, and Rothuizen, J. (2001). Chronic hepatitis in the dogs. A review. Vet. Q.32: 14-52.

Sterczer, A., Gaal, T., Perge, E, and Bruss, M.L. eds. Clinical biochemistry of domestic animals, $6^{\text {th }}$ edn. Elsevier Publication, pp: 379-412.

Thyagarajan, S.P., Jayaram, S., Gopala Krishnan, V., Har, R., Jayakumar, P. and Sripathi, M.S. (2002). Herbal medicines for liver diseases in india. $J$. Gastroenterol. Hepatol.17(3): 370-376.

Timmerman, R.J., Springman, F.R. and Thoms, R.K. (1964). Evaluation of furosemide, a new diuretic agent. Curr. Ther. 
Res.6(2):88-94.

Tiwari, P., Varshney, J.P. and Hoque, M. (2001). Biliary obstruction in dogs: diagnosis and treatment. Indian J. Vet. Med.21(2): 115-116.

Trinchet, J. C., Coste, T. and Lévy V. G. (1989). Treatment of alcoholic hepatitis with silymarin. A double-blind comparative study in 116 patients. Gastroenterol. Clin. Biol. 3(2) 120-124.

Twedt, D.C. (2004). Nutraceuticals in liver disease. Proceed $22^{\text {nd }}$ ACVIM Forum, Minneapolis. pp: 678-680.

Varley, H., Grawlock, A.H. and Bell, M. (1980). Practical biochemistry. Vol. 15 edn, Willian Heinmann, Medical book ltd, London, pp: 458-484.

Varshney, J.P. and Hoque, M. (2002).Clinicopathological and ultrasonographic observation in canine hepatopathies. Indian J. Anim. Sci.72(6): 423-427.

Vijayakumar, H., Pandey, N.N., Gurav, A., Mishra, K.K., and Mondal, D.B. (2011). Diagnostic evaluation of ultrasonography in canine hepatobiliary and urinary disorders. Indian J. Anim. Sci.81(2): 162167.

Webster, C.R.L. (2005). History, clinical signs and physical finding in hepato biliary disease. In: ettinger, S.J and Feldman, E.C. eds. Textbook of veterinary internal medicine. Diseases of the dog and cat. Vol. $2^{\text {nd }} \quad 5^{\text {th }}$ edn. $\quad$ Elsevier saunders publication, pp: 1422 .

Webster, C.R.L. (2005). History, clinical signs and physical finding in hepato biliary disease. In: ettinger, S.J and Feldman, E.C. eds. Textbook of veterinary internal medicine. Diseases of the dog and cat. Vol. $2^{\text {nd }} \quad 5^{\text {th }}$ edn. $\quad$ Elsevier saunders publication, pp: 1422 .

Wilkinson, J.H. and Winsten, S. (1969). Evaluation of a new system for the kinetic measurement of Serum Alkaline Phosphatase. Clin. Chem.15: 487 - 495.

Willard, M.D. and Tvedten, H. (1999). Small animal clinical diagnosis by laboratory methods, $4^{\text {th }}$ edn. Saunders publication, pp: 38-61 \& 208-323.

Willard, M.D. and Tvedten, H. (1999). Small animal clinical diagnosis by laboratory methods, $4^{\text {th }}$ edn. Saunders publication, pp: 38-61 \& 208-323.

\section{How to cite this article:}

Sachin Kumar Singh, S. K. Shukla, Prakash Bhatt and Singh, A. K. 2019. Clinico Therapeutic Studies on Ascites in Canines. Int.J.Curr.Microbiol.App.Sci. 8(09): 1120-1137.

doi: https://doi.org/10.20546/ijcmas.2019.809.129 